\title{
Sleeping Pattern of Depressed Elders Living in Elderly Homes
}

\author{
Magdala Habib Farid Maximos*, Rasha Ahmed Fouad ${ }^{\dagger}$.
}

\begin{abstract}
Sleep disorders are common and significant complaints of depressed older people. A large proportion of depressed older people are at risk for sleep disturbances, which may be caused by many factors. It was thus the intent of this study to assess the sleeping pattern of depressed elders living in elderly homes. Results of the present study revealed that, the majority of the studied depressed elders had sleeping difficulties and more than half of them took more than 60 minutes in bed to fall asleep. Almost all the subjects woke up more than 3 times during the night, and the most frequently reported causes were frequency of micturition, anxiety, and pain. Three-quarters of the studied elders did not feel comfortable when waking up in the morning, and this affected their ability to perform their daily living activities. It is thus recommended to encourage elderly clients to establish a routine sleep schedule, to stick to rituals that help to relax before bed time and to suggest consultation with appropriate specialist depending on the underlying causes of the sleep disorder.
\end{abstract}

\section{INTRODUCTION}

Sleep is a basic human need. It is a in the older adult, this is not normal. More universal process common to all people ${ }^{(1)}$. It than half of all older adults report problems serves as a restorative function both with sleep; up to two-thirds of older adults physically and psychologically and is living in nursing homes are also affected (4). considered one of the major aspects of health Unfortunately, these numbers may be an promotion for older adults ${ }^{(2)}$. Approximately underestimation because older adults with one-third of a person's lifetime is spent in cognitive impairments may not be able to sleep. For optimal day time alertness, elderly report sleep disturbances or even realize that require about six and half hours of sleep per they have not slept. Among older adults with day ${ }^{(3)}$. Older adults frequently complain about sleep disturbances, $69 \%$ do not report this sleep disturbances. Although difficulties in problem to their health care providers ${ }^{(5)}$. Even falling asleep or staying awake are common when they report sleep problems, physicians ${ }^{*}$ Psychiatric and Mental Health Nursing, + Gerontological Nursing, Faculty of Nursing, Alexandria University 
often under diagnose or do not recognize signs and symptoms of sleep disturbances in the older adult. With aging, differences in sleep are recognized by decreases in duration, depth, and continuity of restful sleep $^{(6,7)}$.

Although some problems about the quality of sleep may be attributed to age-related changes, most sleep disturbances of depressed elders in elderly homes are the results of many factors which may be psychological, physical, and/or intake of some medications. As well as due to changes from usual nighttime routines at homes, inactivity, and conditions in the environment such as temperature, noise, and bright lighting(8).

Multiple losses associated with aging, Ioneliness, decline in physical health, and relocation to an elderly home are stressors that have a negative impact on the psychological status of elders, and the development of depression is usually a common reaction to such losses ${ }^{(9)}$. Lachine 1998 reported that $54.1 \%$ of the institutionalized elders were suffering from severe and extreme depression ${ }^{(10)}$.

The most common cause of sleep problems in many older adults is depression. Bereavement is also a common cause of sleep disorders, primarily because bereavement results in depression. Depressed people commonly wake up early in the morning, take longer to get to sleep, and wake up often during the night. Several studies revealed that not sleeping well can lead to a number of problems; older adults who have poor nighttime sleep are more likely to have a depressed mood, attention and memory problems, irritability and poor judgment, injury or other health conditions, excessive daytime sleepiness, more nighttime falls, and use more over-thecounter or prescription sleep aids. Moreover, poor sleepers are also associated with a poorer quality of life; visit their health care providers more often, and rate their health as poorer than that of other people ${ }^{(11,12)}$.

Most elderly people assume the average sleep disorder as a minor problem that a simple over the counter sleeping aid can cure. In some cases, this is accurate. In other 
cases, such a casual attitude towards sleeping disorders has a highly negative effect. So, it is important for nurses as well as other health care professionals working with older adults to assess and evaluate their sleeping pattern in order to identify factors affecting sleep and institute appropriate measures to overcome any sleep disturbances to improve the quality of life for older adults ${ }^{(13)}$.

\section{AIM OF THE STUDY}

The aim of this study was to identify the sleeping pattern among depressed elders living in elderly homes.

\section{MATERIAL AND METHOD}

\section{Materials}

\section{Study Design:}

The design followed for this study is a cross-sectional design.

\section{Settings:}

This study was carried out in three governmental elderly homes in Alexandria, namely Dar El-Hana, Dar El-Hedaya, and Dar El-Saada. Those elderly homes were selected by ballot, out of the six governmental elderly homes in Alexandria. Dar El-Hana and
Dar El-Hedaya are for females, while Dar ElSaada is for males.

\section{Subjects:}

Males and females, aged 60 years and above, who accepted to participate in the study, and were available at the time of data collection were interviewed using the Geriatric Depression Scale. Their total number amounted to 163 residents. Those who had mild-moderate and/or severe depression according to the Geriatric Depression Scale were included in the study. Their number amounted to 71 residents.

\section{Tools of data collection:}

In order to collect the necessary information for the study three tools were used.

Tool I: The Geriatric Depression Scale (GDS):

The scale was developed by Yesavage, $1983^{(14)}$, and has been used extensively with older population. The scale has been translated to Arabic language, tested for its content validity and reliability and applied on Egyptian people by Abd El-Samie (2000)(15). GDS is a brief questionnaire in which 
participants are asked to respond to 30 questions by answering Yes or No in reference to how the elders felt on the past week of administration of the scale. Scores of 0-9 are considered normal, 10-19 indicate mild-moderate depression, and 20-30 indicate severe depression ${ }^{(16)}$.

Tool II: The Epworth Sleepiness Scale (ESS):

This scale was designed by Johns (1991). It is a valid instrument used to measure excessive daytime sleepiness. The ESS differentiates between average sleep and significant issues with sleepiness that requires intervention. The client self-rates on how likely it is that he/she would doze in eight different situations. Scoring of the answers is $0-3$, with 0 being "Would never doze" and 3 being "high chance of dozing" A sum of 9 or more from the eight individual scores reflects" very sleepy and should seek medical

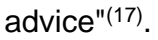

Tool III: Functional Outcomes of Sleep Questionnaire:

It was developed by Weaver et al., and used to evaluate the impact of disorders of excessive sleepiness on activities of daily living. This questionnaire covered the following aspects: activity level, vigilance, general productivity, and social outcome. The respondents were asked to rate the difficulty of performing a given activity as "no difficulty" or "difficulty", where low scores indicated greater dysfunction ${ }^{(18)}$.

In addition, a socio-demographic and clinical data questionnaire was constructed by the researchers to elicit data about the general socio-demographic characteristics of the studied elders such as age, sex, level of education, marital status, occupation before retirement, income and its source, and clinical data which included medical health status, and type of medications used. As well as information related to items about the elders sleeping pattern which include: usual time of going to bed, habits before sleep, activities before bed time, preferred night light environment, day time sleepiness, naps, and behavior on awakening.

Methods

Before the conduction of the study, official letters from the Faculty of Nursing, Alexandria 
University were forwarded to the Ministry of

Social Solidarity and the directors of the selected residential homes to obtain their assistance and approval to interview the residents.

The director of each of the elderly homes was informed about the purpose of the study, and time of starting the data collection.

\section{Pilot study:}

After the development of the tools for data collection, a pilot study was carried out on 10 residents from the private elderly home "Dar Mohamed Ragab".

According to the results of the pilot study, some modifications were done in tool III. Some statements were not clear for the clients, and had to be remolded.

\section{Collection of data:}

The Epworth Sleepiness Scale (Tool II) and The Functional Outcomes of Sleep Questionnaire (Tool III) were translated to Arabic language by the researchers and tested for its translation and content validity by a group of 5 experts in the nursing field. The required modifications were carried out accordingly. Then test-retest reliability was applied to ascertain the reliability of the tool. The tool proved to be strongly reliable $(r=$ 0.9222).

Data collection was done during the period from September to November 2006. The Epworth Sleepiness Scale (Tool II), and The Functional Outcomes of Sleep Questionnaire (Tool III), as well as the sociodemographic data and sleeping pattern questionnaires were applied to the residents with mild to moderate and/or severe depression. Establishment of trustful relationship with those residents was important to obtain their cooperation and gain their confidence before any attempt to collect data. Collection of data was done after explaining the purpose of the study to the elders and assuring them of its confidentiality. Each elderly person was interviewed individually to respect their privacy. It took nearly $30-45$ minutes to complete the questionnaires.

\section{Statistical analysis:}

After data were collected, they were coded and transferred into special designed 
formats so as to be suitable for computer feeding.

Following data entry, checking and verification processes were carried out to avoid any errors during data entry.

The SPSS program (Statistical Package for Social Sciences) V 13.0 was used for statistical processing and analysis.

The following statistical measures were used:

a) Descriptive measures used included: frequencies, percentages, arithmetic means, and standard deviations.

b) Statistical tests included:

- Chi-square test for comparing categorical variables.

$$
\chi^{2}=\square \sum \frac{\left(O_{i}-E_{i}\right)^{2}}{E_{i}}
$$

$\mathrm{O}=$ Observed cell frequency

$E=$ Expected cell frequency

The chi-square test is not valid if more than $20 \%$ of the cells have expected values $<5$ or if the expected value of one or more cells $=0$ in which case the Fisher's exact test is used.

- Fisher's Exact Test probability for Fourfold Tables:

$$
\mathrm{P}=\frac{R_{1} ! R_{2} ! C_{1} ! C_{2} !}{N ! O_{1} ! O_{2} ! O_{3} ! O_{4} !}
$$

$$
\begin{aligned}
& \mathrm{R}=\text { Row total } \\
& \mathrm{C}=\text { Column total } \\
& \mathrm{O}=\text { Observed cell frequency } \\
& \mathrm{N}=\text { Sample size } \\
& \text { ! = Factorial }
\end{aligned}
$$

The formula can be extended for larger tables according to the same pattern.

- The level of significance selected for this study was $\mathrm{P}$ less than 0.05 .

\section{RESULTS}

Table 1 shows the socio-demographic characteristics of depressed elderly homes residents. The age of the residents ranged from 60 to more than 85 years with a mean of $76.34 \pm 9.69$ years. The young old (those aged 60 to less than 75 years) constituted half of the subjects (50.7\%), and $26.8 \%$ were old-old (85 years and more). Females constituted $71.8 \%$ of the subjects. More than four-fifths of the studied subjects (84.5\%) were widowed; and only $5.6 \%$ were still married. Illiteracy is prevailing among nearly half of the studied subjects $(49.3 \%)$, while $23.9 \%$ could just read and write or had a primary education. As 
regard the occupation of the elders before retirement, it appears from the table that, twothirds of the residents were housewives $(66.2 \%)$, employees and skilled workers represent $28.2 \%$ and $5.6 \%$, respectively of the studied subjects. The monthly income of the residents ranged from less than 200 to more than 600 Egyptian pounds with a mean of $414.79 \pm 223.67$. Nearly one-third of the residents (32.4\%) mentioned that they have an income of less than LE 200. While $14.1 \%$ had an income of 200 to less than LE 400 . The source of income was mainly the pension for $66.2 \%$ and for the rest it was either from relatives and friends, or from the social affairs (29.6\% and $4.2 \%$, respectively). The duration of stay in the home was for more than one year for the majority of the elders (85.9\%) and less than one year for only $14.1 \%$. Nearly half of the residents (46.5\%) are living alone in a room, $19.7 \%$ of them share their room either with one client or with three clients and more.

Table 2 shows the distribution of depressed elderly homes residents according to their participation in leisure activities and exercises. The findings indicated that almost three-quarters of the depressed elders (73.2\%) were participating in recreational activities, followed by $70.4 \%$ doing physical activities, and only $8.4 \%$ who practiced religious activities. On the other hand, $22.5 \%$ of the studied elders were not doing any activity. Social and creative activities were not practiced by any of them. Regarding routine physical exercises, the same table revealed that around half of the depressed elders (49.3\%) are regularly performing exercises, compared to $29.6 \%$ who had never performed any type of exercise. Walking is the most frequently practiced exercise by them; it was reported by $74.0 \%$ of them inside the elderly home and $10.0 \%$ outside it. Range of motion exercises were reported by $46.0 \%$ of the studied elders. The majority of elders $(80.0 \%)$ reported that the frequency of doing exercises was about three times and more per week. More than half of them (52.0\%) reported that they spent 15 minutes in performing exercises compared to only $18.0 \%$ who spent 60 minutes and more.

Table 3 presents the environmental 
factors affecting the sleep of depressed elderly homes residents. It was found that the majority of the studied elders reported suitable room ventilation $(91.6 \%)$, suitable light $(88.7 \%)$, and suitable temperature (54.9\%). Regarding the presence of noise, more than one-quarter of depressed elders (29.6\%) reported that noise affected their sleep. Among the causes of noise reported by elders inside the elderly homes, they mentioned other residents, radio or TV, and caregivers $(61.9 \%, \quad 52.4 \%$, and $23.8 \%$ respectively). Among the causes of noise outside the elderly homes, cars and microphone were mentioned by $47.2 \%$ of the elders.

Table 4 represents the sleeping pattern of depressed elderly homes residents. It was noticed that almost one-third of the studied elders $(32.4 \%)$ mentioned that they watched TV or listened to radio daily before going to sleep, followed by $25.3 \%$ who mentioned invoking God. Listening to music or talking with friends were reported by the same percent $(5.6 \%)$, while only a small percent (2.8\%) mentioned reading or taking light meals before going to sleep. The majority (86.0\%) also performed these previously mentioned habits in bed. The majority of elders $(81.7 \%)$ said that they immediately go to bed when they feel the desire to sleep, while $80.3 \%$ reported that they had not a fixed time for sleep. Drinking fluids before sleep was mentioned by $88.7 \%$ of the elders.

Regarding difficulty to fall asleep, the table revealed that $94.4 \%$ of the studied elders reported that they had difficulty to fall asleep and more than one half $(53.5 \%)$ spent 60 minutes and more in bed to fall asleep, followed by around one-third (35.2\%) who spent 45 to less than 60 minutes. If the time spent in bed awake increased, $56.3 \%$ of the studied elders invoked God, followed by $30.9 \%$ who watched TV or listened to radio in bed, $23.9 \%$ stayed in bed doing nothing, while only $2.8 \%$ went out of bed and drank warm fluids. All the studied elders reported that they woke up during the night, $59.2 \%$ of them woke up three times and more. The majority of elders reported that the causes of waking up were frequency of micturition (85.9\%), anxiety (54.9\%), pain (49.3\%), 
acidity $(21.1 \%)$, cough $(18.3 \%)$, for prayers (11.2\%), dyspnea, hunger, and thirst, as well as naps were reported by small percentages. The majority of the studied elders (81.7\%) reported that they found difficulty to sleep again when waking up during the night.

As regard the number of sleeping hours during the day and night, more than one half of the elders $(52.2 \%)$ sleep one to less than 3 hours/day, those who sleep 4 hours and more during the day represent $17.4 \%$. Also more than two-fifths $(42.3 \%)$ of the elders sleep 6 to less than 10 hours during the night, followed by nearly one-quarter (23.9\%) who sleep 10 to less than 12 hours, and $18.3 \%$ sleep 12 hours and more during the night. The majority of elders (85.9\%) spent 12 hours and more in bed during the day.

The same table revealed that approximately three-quarters of the studied elders $(74.6 \%)$ reported that they do not feel comfortable when waking up in the morning. Among the causes reported for not feeling comfortable, the elders mentioned muscle pain $\quad(75.5 \%)$, tiredness $\quad(62.3 \%)$, disorientation (39.6\%), irritability and feeling of tightness (22.6\%), and lack of concentration (15.1\%).

Table 5 shows the subjective experience of sleep and performance of activities of daily living of depressed elderly homes residents. It was found that, two-fifths of the studied elders $(40.8 \%)$ reported their general state of sleep as bad, and $22.5 \%$ described it as very good. Regarding their difficulties in performing daily living activities, it was found that, more than one-third of elders $(35.2 \%)$ were able to perform activities of daily living (ADL) without difficulties, while $18.4 \%$ were unable to perform $A D L$ and found great difficulties.

Table 6 shows the relation between the Epworth Sleepiness Scale, the Functional Outcomes of Sleep Questionnaire, and the studied elders' sex. It was observed that more than two-fifths of the studied elders (23.9\%) were getting enough sleep $(25.0 \%$ of the males compared to $23.5 \%$ of the females). On the other hand, $20.0 \%$ of male elders were very sleepy and this percentage increased to almost the double for females (49.0\%). Comparing both sexes, statistically 
significant difference was observed $\chi^{2}=$ sleeping pattern of depressed elderly homes

$6.071(P=0.048$; the level of significance selected for this study was $P$ less than 0.05$)$.

Regarding Functional outcomes of sleep questionnaire the same table illustrates that $63.4 \%$ of the studied elders had difficulty to perform activity $(40.0 \%$ of the males compared to $72.5 \%$ of the females). While no difficulty to perform activity was found in only $36.6 \%$ of the studied elders $(60.0 \%$ of the males compared to $27.5 \%$ of the females). A statistically significant difference was observed as $\chi^{2}=6.558, P=0.010$.

Table 7 shows the relation between the Epworth Sleepiness Scale and the Functional outcomes of sleep questionnaire. It was found that $64.4 \%$ of very sleepy elders had difficulty to perform activity. While only $6.7 \%$ who are getting enough sleep reported difficulty to perform activity. On the other hand, more than half of the elders getting enough sleep (53.8\%) had no difficulty to perform activity. The difference was statistically significant $\quad F E T=33.471$, $(P=0.000)$.

Table 8 shows the relation between the residents and their level of depression. It was found that, $85.70 \%$ of severely depressed elders spend 12 hours and more in bed during the night compared to $85.90 \%$ for those who have mild-moderate depression. On the other hand, $14.30 \%$ of severely depressed elders spend less than 12 hours in bed during the night compared to $12.50 \%$ of those with mild-moderate depression. The difference isn't statistically significant FET = $1.075(P=1.000)$. The same table revealed that the majority of elders with mild-moderate depression $(71.90 \%)$ compared to all those with severe depression, reported that they do not feel comfortable when waking up in the morning. The difference is statistically significant $F E T=1.381(P=0.037)$. Regarding their general state of sleep, the table revealed that nearly three- quarters $(71.40 \%)$ of elders with severe depression reported a good state of sleep compared to $45.70 \%$ for those with mild-moderate depression. While $28.60 \%$ of the severely depressed elders reported their state of sleep as bad and this percentage increased to approximately the double 
$(54.70 \%)$ for those having mild-moderate depression. The difference is statistically significant $F E T=6.793(P=0.040)$.

\section{DISCUSSION}

The aging process is associated with physiological, psychological, and social changes that put elders at high risk for the development of depression(19). Recognizing depression in the older person is not always easy, since it is often masked by other problems such as physical ailments, memory loss, confusion, lack of appetite, and disturbed sleep patterns ${ }^{(20)}$.

Sleep complaints are common among elderly people, and the incidence of sleep problems increases with age. Older adults experience age-related changes in the nature of their sleep, more frequent awakenings, decreased amounts of nighttime sleep, and more frequent daytime napping ${ }^{(21)}$. Bixler et al., 2005 reported in their study that as many as $42 \%$ of older adults reporting both difficulty falling asleep and difficulty staying asleep ${ }^{(22)}$. This is in accordance with the results obtained in the present study, as more than half of the studied subjects reported difficulty initiating sleep and waking up three times and more during the night. Almost similar findings were reported by another Egyptian study done in Alexandria by Makhlouf et al., (2007), who mentioned that $65 \%$ of the participants reported difficulty initiating sleep as well, and approximately half of them had difficulty maintaining their sleep ${ }^{(23)}$. Elders in the hospital or nursing home are even more likely to experience fragmented sleep than their counterparts in the community ${ }^{(24)}$. Results of the present study revealed that difficulty to fall asleep was reported by the majority of the studied depressed elders. Sukegawa (2003), supported this finding by his study done in Japan and mentioned that poor sleep efficiency and sleep disturbances due to difficulty of initiating sleep, were characteristics of the depressed elderly(25).

Another study done in the United State by Zulley et al., (2001) revealed that $13 \%$ of men and $36 \%$ of women aged 60 years and more take more than 30 minutes to fall asleep ${ }^{(26)}$. A possible explanation for changes in older adults' sleep patterns is that older adults may 
produce and secrete less melatonin, the hormone that promotes sleep. Frequent awakening was found to be related to several reasons, the majority of the studied elders in the present study said that frequent awakening was because of the need to go to the bathroom. For such elders getting back to sleep was difficult. This finding is expected and understandable because of the alterations occurring with the aging process in the urinary system.

Pain as a source of sleep disturbance was reported by approximately half of the elders in the present study, bodily pain, acute or chronic interference with falling asleep and with staying asleep. This finding is in line with other studies $^{(27,28)}$.

Sleep disruption in older persons with psychological problems as depression may result from personal characteristics, environmental characteristics, or a combination of these factors. The environment can positively or negatively influence the quality and amount of sleep the person receives. For older adults, environments conducive to relaxation are likely to be soporific. Such environments include low level of stimuli, dimmed light, silence, and comfortable bed ${ }^{(13)}$. The sleep of many depressed elderly homes' residents in the present study was disrupted by a variety of sources of disturbances. Environmental noise potentially interferes with sleep in all heath care settings, it was reported by about more than one-quarter of elders. Noise as a major source of disturbance is in accord with others ${ }^{(29,30)}$. Noise as reported by elders in the present study was due to many reasons including the other residents, radio or TV, and the caregivers. Also, noise coming from outside the elderly home was reported as cars and microphones. They are also more easily aroused from sleep by environmental stimuli such as noise, changes in temperature, and/or light. Moreover, nearly half of the residents in the present study reported that falling asleep and staying asleep is difficult when they are feeling cold, older adults may wake during the night because of a nighttime reduction in core body temperature related to reduced metabolic rate and muscular activity. 
As a result, sleep becomes increasingly fragmented and sleep efficiency (the ratio of time spent sleeping to time spent in bed) decreases. Environmental light can interfere with the sleep of residents; most elders in the present study were accustomed to sleep in darkened rooms.

There is a common misconception that as people gets older; they need to slow down ${ }^{(31)}$. Physical activity have a broader significance for the overall wellbeing of elders such as mood improvement, sense of well being, lower occurrence of depressive symptoms and sleep improvement ${ }^{(8)}$. Sleep and activity are halves that combine to make the wholeness of our days. Without sleep, elders are not restored from the previous day's efforts and today's activities are slowed by fatigue. Without activities the elders face going to bed without feeling the necessity of rest. Without the appropriate balance of sleep and activity the elders are at risk of alterations in health ${ }^{(32)}$. Consequences of sleep loss in the elders may adversely affect their activities of daily living. Physical activity includes activities of daily living ( $A D L)$ and exercises. ADL is considered the index of functional ability of elders. This was observed in the present study as more than half of those who mentioned getting enough sleep according to the Epworth Sleepiness Scale, reported no difficulty to perform activities. The findings of the present study indicated that walking is the most frequently practiced exercise by elders. However, more than onequarter of the studied subjects do not practice any type of physical exercise. This is probably due to the lack of space in some of the studied homes, like narrow corridors. As well, lack of motivation, lack of companionship, and fear from being lost around or falling, may be the reasons. This may also be due to their life style pattern during early life and adulthood. This supports the findings of other studies ${ }^{(33,34)}$.

\section{CONCLUSION \& RECOMMENDATIONS}

From the findings of the present study, it can be concluded that although sleep disturbance is a chronic health problem common in older adult, specially depressed ones, it remains a neglected problem for both, those who are afflicted and those who 
care for them. One may conclude that sleep disturbance and depression among the institutionalized elders are closely related symptoms. The depressive status of elders was significantly associated with an increased risk of difficulty to fall asleep, daytime sleepiness, and waking up during the night, and this affected their ability to perform their daily living activities.

Based on the findings of this study, the following recommendations are suggested:-

- Cognitive behavioral therapy should be planned to improve both immediate and long-term self-reported sleep disorder. It focuses on changing the depressed elder's expectations about sleep, as many depressed older persons worry about their inability to sleep and become anxious "trying" to sleep.

- Regular exercise, social activities, combined with sleep hygiene education are required to improve sleep and quality of life in older adults with sleep disorders. Nursing care should be organized to reduce the sources of sleep disturbance to a minimum.

- Nurses and or caregivers need to be knowledgeable that, although sleep patterns change as people age, disturbed sleep and waking up tired every day are not part of normal aging. Those who have trouble sleeping are advised to see a physician.

- Instruct the residents in elderly homes to stick to rituals that help to relax each night before bed. The environment as well should not be conducive to sleep disturbance.

- In the nursing assessment of the older adults, a detailed history of their sleep pattern before institutionalization should be secured, to detect any deviation from normality during their stay in the elderly home and deal with it. 
Table 1: Socio-demographic characteristics of depressed elderly homes residents.

\begin{tabular}{|c|c|c|}
\hline Item & $(n=71)$ & $\%$ \\
\hline \multicolumn{3}{|l|}{ Age (years) } \\
\hline $60-$ & 36 & 50.7 \\
\hline $75-$ & 16 & 22.5 \\
\hline 85 or more & 19 & 26.8 \\
\hline Mean \pm SD & \multicolumn{2}{|c|}{$76.34 \pm 9.69$} \\
\hline \multicolumn{3}{|l|}{ Sex } \\
\hline Males & 20 & 28.2 \\
\hline Females & 51 & 71.8 \\
\hline \multicolumn{3}{|l|}{ Marital status } \\
\hline Widowed & 60 & 84.5 \\
\hline Single & 6 & 8.5 \\
\hline Married & 4 & 5.6 \\
\hline Divorced & 1 & 1.4 \\
\hline \multicolumn{3}{|l|}{ Education } \\
\hline Illiterate & 35 & 49.3 \\
\hline Read and write/Primary & 17 & 23.9 \\
\hline Preparatory/Secondary & 15 & 21.2 \\
\hline University and higher & 4 & 5.6 \\
\hline \multicolumn{3}{|l|}{ Occupation } \\
\hline House wife & 47 & 66.2 \\
\hline Employee & 20 & 28.2 \\
\hline Skilled worker & 4 & 5.6 \\
\hline \multicolumn{3}{|l|}{ Income } \\
\hline$<200$ & 23 & 32.4 \\
\hline $200-$ & 10 & 14.1 \\
\hline $400-$ & 18 & 25.3 \\
\hline $600+$ & 20 & 28.2 \\
\hline Mean \pm SD & \multicolumn{2}{|c|}{$414.79 \pm 223.67$} \\
\hline \multicolumn{3}{|l|}{ Source of income } \\
\hline Pension & 47 & 66.2 \\
\hline Relatives or friends & 21 & 29.6 \\
\hline Social assistance & 3 & 4.2 \\
\hline \multicolumn{3}{|l|}{ Institutionalization: } \\
\hline$<$ one year & 10 & 14.1 \\
\hline One year + & 61 & 85.9 \\
\hline \multicolumn{3}{|l|}{ Living in room: } \\
\hline Alone & 33 & 46.5 \\
\hline With one client & 14 & 19.7 \\
\hline With two clients & 10 & 14.1 \\
\hline $\begin{array}{l}\text { With three clients and } \\
\text { more }\end{array}$ & 14 & 19.7 \\
\hline
\end{tabular}


Table 2: Distribution of depressed elderly homes residents according to their participation in leisure activities and exercises

\begin{tabular}{|c|c|c|}
\hline \multirow{2}{*}{\multicolumn{3}{|c|}{$\begin{array}{ll} & \text { Item } \\
\text { Spending leisure time* }\end{array}$}} \\
\hline & & \\
\hline Not doing any activity & 16 & 22.5 \\
\hline Recreational activities & 52 & 73.2 \\
\hline Physical activities "exercises" & 50 & 70.4 \\
\hline Religious activities & 6 & 8.4 \\
\hline Social activities & 0 & 0.0 \\
\hline Creative activities & 0 & 0.0 \\
\hline \multicolumn{3}{|l|}{ Performing routine physical exercise } \\
\hline Never & 21 & 29.6 \\
\hline Sometimes & 15 & 21.1 \\
\hline Regularly & 35 & 49.3 \\
\hline Types of exercises* & $(n=50)$ & \\
\hline Walking inside elderly home & 37 & 74.0 \\
\hline Walking outside elderly home & 5 & 10.0 \\
\hline Range of motion exercises & 23 & 46.0 \\
\hline Frequency of doing exercises/week & $(n=50)$ & \\
\hline Once/week & 4 & 8.0 \\
\hline Twice/week & 6 & 12.0 \\
\hline Three times and more/week & 40 & 80.0 \\
\hline Time spent in performing exercises & $(n=50)$ & \\
\hline $15 \mathrm{~min}$ & 26 & 52.0 \\
\hline $30 \mathrm{~min}$ & 7 & 14.0 \\
\hline $45 \mathrm{~min}$ & 8 & 16.0 \\
\hline $60 \mathrm{~min}$ and more & 9 & 18.0 \\
\hline
\end{tabular}

* Answers are not mutually exclusive.

Table 3: Sleep related environmental factors reported by depressed elderly homes' residents.

\begin{tabular}{c|c|c}
\hline \multicolumn{1}{c|}{ Item } & $(\mathbf{n = 7 1 )}$ & $\%$ \\
\hline Suitable Room ventilation & & \\
Yes & 65 & 91.6 \\
No & 6 & 8.4 \\
\hline Room light & 63 & \\
Suitable light & 8 & 88.7 \\
Excessive light & & 11.3 \\
\hline Room temperature & 39 & \\
Suitable temp. & 32 & 54.9 \\
Low temp. & & 45.1 \\
\hline Presence of noise & 50 & 70.4 \\
No & 21 & 29.6 \\
Yes & $\mathbf{( n = 2 1 )}$ & \\
\hline Causes of noise* & 13 & 61.9 \\
Residents & 11 & 52.4 \\
Radio or TV. & 5 & 23.8 \\
Caregivers & 10 & 47.2 \\
Cars and microphones
\end{tabular}

${ }^{*}$ Answers are not mutually exclusiv 
Table 4: Sleeping pattern of depressed elderly homes residents

\begin{tabular}{|c|c|c|}
\hline Item & $(n=71)$ & $\%$ \\
\hline \multicolumn{3}{|l|}{ Habits before going to sleep ${ }^{\star}$} \\
\hline Doing nothing & 21 & 29.6 \\
\hline Watching TV or listening to radio & 23 & 32.4 \\
\hline Praying and invoking god & 18 & 25.3 \\
\hline Listening to music & 4 & 5.6 \\
\hline Talking with friends & 4 & 5.6 \\
\hline Reading & 2 & 2.8 \\
\hline Taking light meals & 2 & 2.8 \\
\hline Performance of any mentioned previous habits in bed & $(n=50)$ & \\
\hline Yes & 43 & 86.0 \\
\hline No & 7 & 14.0 \\
\hline \multicolumn{3}{|l|}{ Immediately going to bed when desired to sleep } \\
\hline Yes & 58 & 81.7 \\
\hline No & 13 & 18.3 \\
\hline \multicolumn{3}{|l|}{ Fixed time for sleep } \\
\hline No & 57 & 80.3 \\
\hline Yes & 14 & 19.7 \\
\hline \multicolumn{3}{|l|}{ Drinking fluids before sleep } \\
\hline No & 8 & 11.3 \\
\hline Yes & 63 & 88.7 \\
\hline Types of fluids consumed* & $(n=63)$ & \\
\hline Water and juices & 50 & 79.3 \\
\hline Tea & 42 & 66.6 \\
\hline Herbal infusions & 15 & 23.8 \\
\hline Coffee & 2 & 3.2 \\
\hline \multicolumn{3}{|l|}{ Found difficulty to fall asleep } \\
\hline No & 4 & 5.6 \\
\hline Yes & 67 & 94.4 \\
\hline \multicolumn{3}{|l|}{ Time spend in bed to sleep } \\
\hline $30<45 \mathrm{~min}$ & 4 & 5.6 \\
\hline $45<60 \mathrm{~min}$ & 25 & 35.2 \\
\hline $60+\min$ & 38 & 53.5 \\
\hline \multicolumn{3}{|l|}{ If time spent in bed increased ${ }^{\star}$} \\
\hline Invoking god in bed & 40 & 56.3 \\
\hline Watching TV or listening to radio in bed & 22 & 30.9 \\
\hline Doing nothings & 17 & 23.9 \\
\hline Go out of bed and drinking warm fluids & 2 & 2.8 \\
\hline
\end{tabular}

${ }^{*}$ Answers are not mutually exclusive. 
Table 4: Continued

\begin{tabular}{|c|c|c|}
\hline Item & $(n=71)$ & $\%$ \\
\hline Waking up during the night: & 71 & 100.0 \\
\hline \multicolumn{3}{|l|}{ Numbers } \\
\hline Once /night & 15 & 21.1 \\
\hline Twice /night & 14 & 19.7 \\
\hline Three times and more /night & 42 & 59.2 \\
\hline \multicolumn{3}{|l|}{ Causes* } \\
\hline Frequency of micturition & 61 & 85.9 \\
\hline Anxiety & 39 & 54.9 \\
\hline Pain & 35 & 49.3 \\
\hline Acidity & 15 & 21.1 \\
\hline Cough & 13 & 18.3 \\
\hline Praying & 8 & 11.2 \\
\hline Dyspnea & 7 & 9.8 \\
\hline Hungry and thirsty & 6 & 8.4 \\
\hline Naps & 4 & 5.6 \\
\hline Having difficulty to sleep again & 58 & 81.7 \\
\hline Number of sleeping hours during the day & $(n=46)$ & \\
\hline 1 hour - & 24 & 52.2 \\
\hline 3 hours - & 14 & 30.4 \\
\hline 4 hours and more & 8 & 17.4 \\
\hline Mean \pm SD & \multicolumn{2}{|c|}{$2.36 \pm 0.934$} \\
\hline \multicolumn{3}{|l|}{ Number of sleeping hours during the night } \\
\hline$<4$ hours & 11 & 15.5 \\
\hline 6 hours $<10$ hours & 30 & 42.3 \\
\hline 10 hours $<12$ hours & 17 & 23.9 \\
\hline 12 hours and more & 13 & 18.3 \\
\hline Mean \pm SD & \multicolumn{2}{|c|}{$3.11 \pm 1.399$} \\
\hline \multicolumn{3}{|l|}{ Total hours in bed } \\
\hline Less than 12 hours & 10 & 14.1 \\
\hline More than 12 hours & 61 & 85.9 \\
\hline $\begin{array}{l}\text { Not feel comfort when waking in the morning } \\
\text { Causes* }\end{array}$ & $\begin{array}{l}53 \\
(n=53)\end{array}$ & 74.6 \\
\hline Muscle pain & 40 & 75.5 \\
\hline Tired & 33 & 62.3 \\
\hline Disorientation & 21 & 39.6 \\
\hline Irritability and feeling of tightness & 12 & 22.6 \\
\hline Lack of concentration & 8 & 15.1 \\
\hline
\end{tabular}

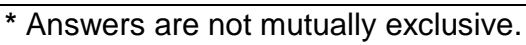


Table 5: Depressed elderly homes residents' subjective experience of sleep and performance of activities of daily living.

\begin{tabular}{l|c|c}
\hline \multicolumn{1}{c|}{ Item } & $(\mathbf{n}=\mathbf{7 1})$ & $\%$ \\
\hline Describe your general state of sleep & & \\
Very good & 16 & 22.5 \\
Good & 18 & 25.3 \\
Bad & 29 & 40.8 \\
Very bad & 8 & 11.4 \\
\hline Difficulties in performing daily living activities & & \\
No difficulties & 25 & 35.2 \\
Few difficulties & 17 & 23.9 \\
Many difficulties & 16 & 22.5 \\
Unable to perform ADL & 13 & 18.4 \\
\hline
\end{tabular}

Table 6: Relation between the Epworth Sleepiness Scale, Functional outcomes of sleep questionnaire and the studied elders' sex.

\begin{tabular}{c|c|c|c|c}
\hline Scale & $\begin{array}{c}\text { Males } \\
\mathbf{n = 3 5} \\
\%\end{array}$ & $\begin{array}{c}\text { Females } \\
\mathbf{n = 6 5} \\
\%\end{array}$ & $\begin{array}{c}\text { Total } \\
\mathbf{n}=71 \\
\%\end{array}$ & $\begin{array}{c}\text { Test of } \\
\text { Significance }\end{array}$ \\
\hline $\begin{array}{c}\text { Epworth Sleepiness Scale } \\
\text { Getting enough sleep }\end{array}$ & 25.0 & 23.5 & 23.9 & \\
Average hours of sleep & 55.0 & 27.5 & 35.3 & $\begin{array}{c}\chi^{2}=6.071 \\
\mathrm{P}=0.048^{*}\end{array}$ \\
$\begin{array}{c}\text { Very sleepy } \\
\begin{array}{c}\text { Functional outcomes of } \\
\text { sleep questionnaire } \\
\text { Good functional }\end{array}\end{array}$ & 20.0 & 49.0 & 40.8 & \\
$\begin{array}{c}\text { outcome } \\
\text { Bad functional outcome }\end{array}$ & 40.0 & 72.5 & 63.4 & \\
\hline
\end{tabular}

* significant value at $\mathrm{P}<0.05$ 
Table 7: Relation between Epworth sleepiness scale and Functional outcomes of sleep questionnaire

\begin{tabular}{|c|c|c|c|c|}
\hline \multirow[b]{2}{*}{$\begin{array}{c}\text { Functional } \\
\text { outcomes } \\
\text { of sleep } \\
\text { questionnaire }\end{array}$} & \multicolumn{3}{|c|}{ Epworth Sleepiness Scale } & \multirow[b]{2}{*}{$\begin{array}{c}\text { Test of } \\
\text { Significance }\end{array}$} \\
\hline & $\begin{array}{l}\text { Getting } \\
\text { enough } \\
\text { sleep }\end{array}$ & $\begin{array}{c}\text { Averag } \\
\text { e hours } \\
\text { of } \\
\text { sleep }\end{array}$ & $\begin{array}{l}\text { Very } \\
\text { sleepy }\end{array}$ & \\
\hline $\begin{array}{l}\text { No difficulty to } \\
\text { perform activity }\end{array}$ & 53.8 & 46.2 & 0.0 & \multirow{2}{*}{$\begin{array}{c}\mathrm{FET}=33.471 \\
\mathrm{P}=0.000^{*}\end{array}$} \\
\hline $\begin{array}{l}\text { Difficulty to } \\
\text { perform activity }\end{array}$ & 6.7 & 28.9 & 64.4 & \\
\hline
\end{tabular}

* significant value at $\mathrm{P}<0.05$

Table 8: Relation between the sleeping pattern of depressed elderly homes residents and their level of depression.

\begin{tabular}{|c|c|c|c|c|c|c|c|}
\hline \multirow[t]{2}{*}{ Sleeping pattern } & \multicolumn{2}{|c|}{$\begin{array}{c}\text { Mild- } \\
\text { Moderate } \\
\text { depression }\end{array}$} & \multicolumn{2}{|c|}{$\begin{array}{c}\text { Severe } \\
\text { Depression }\end{array}$} & \multicolumn{2}{|c|}{ Total } & \multirow[t]{2}{*}{$\begin{array}{c}\text { Test of } \\
\text { Significance }\end{array}$} \\
\hline & $\mathbf{n}$ & $\%$ & $\mathbf{n}$ & $\%$ & $\mathbf{n}$ & $\%$ & \\
\hline $\begin{array}{l}\text { Total hours in bed } \\
\text { Less than } 8 \text { hours } \\
\text { Less than } 10 \text { hours } \\
\text { Less than } 12 \text { hours } \\
12 \text { hours and more }\end{array}$ & $\begin{array}{c}0 \\
1 \\
8 \\
55 \\
\end{array}$ & $\begin{array}{r}0.00 \% \\
1.60 \% \\
12.50 \% \\
85.90 \% \\
\end{array}$ & $\begin{array}{l}0 \\
0 \\
1 \\
6\end{array}$ & $\begin{array}{c}0.00 \% \\
0.00 \% \\
14.30 \% \\
85.70 \% \\
\end{array}$ & $\begin{array}{c}0 \\
1 \\
9 \\
61 \\
\end{array}$ & $\begin{array}{r}0.00 \% \\
1.41 \% \\
12.68 \% \\
85.92 \% \\
\end{array}$ & $\begin{array}{c}\mathrm{FET}=1.075 \\
\mathrm{P}=1.000\end{array}$ \\
\hline $\begin{array}{l}\text { Feeling } \\
\text { comfortable when } \\
\text { waking in the } \\
\text { morning } \\
\quad \text { Yes } \\
\quad \text { No }\end{array}$ & $\begin{array}{l}18 \\
46\end{array}$ & $\begin{array}{l}28.10 \% \\
71.90 \%\end{array}$ & $\begin{array}{l}0 \\
7\end{array}$ & $\begin{array}{c}0.00 \% \\
100.00 \%\end{array}$ & $\begin{array}{l}18 \\
53\end{array}$ & $\begin{array}{l}25.35 \% \\
74.65 \%\end{array}$ & $\begin{array}{c}\mathrm{FET}=1.381 \\
\mathrm{P}=0.037^{*}\end{array}$ \\
\hline $\begin{array}{l}\text { Description of the } \\
\text { general state of } \\
\text { sleep } \\
\qquad \text { Good } \\
\text { Bad }\end{array}$ & $\begin{array}{l}29 \\
35\end{array}$ & $\begin{array}{l}45.30 \% \\
54.70 \%\end{array}$ & $\begin{array}{l}5 \\
2\end{array}$ & $\begin{array}{l}71.40 \% \\
28.60 \%\end{array}$ & $\begin{array}{l}34 \\
37\end{array}$ & $\begin{array}{l}47.89 \% \\
52.11 \%\end{array}$ & $\begin{array}{c}\text { FET }=6.793 \\
P=0.040^{*}\end{array}$ \\
\hline
\end{tabular}

\footnotetext{
* significant value at $\mathrm{P}<0.05$
} 


\section{REFERENCES}

1. Meridean L, Kathleen C. Nursing Care of Older Adults. London: Mosby Co.; 2001; 117-9, 145-55.

2. Almeida $\mathrm{O}$, Tamai $\mathrm{S}$, Garrido. Sleep Complaints among the Elderly: Survey in a Psycho Geriatric outpatient Clinic in Brazil. International Psycho Geriatrics. 1999; 11(1): 47-56.

3. Beck-Little R, Weionrich S. Assessment and Management of Sleep Disorders in the Elderly. Journal of Gerontological Nursing. 1998; 24(40): 21-9.

4. Gentili A, Weiner D, Kuchibhatil E, Edinger J. Factors that Disturb Sleep in Nursing Home Residents. Journal of Aging. 1997; 9(3): 207-13.

5. Hoffman S. Sleep in the older adult: implications for nurses (CE). Geriatr Nurs. 2003; 24(4): 210-4

6. Ayalon L, Liu L, Ancoli S. Diagnosing and treating sleep disorders in the older adult, Med Clin North Am. 2004; 88(1): 737-50.

7. Millman R. Do you ever take a sleep history? Anna Int Med. 1999; 131(1): 535-6.

8. Lueckenotte A. Gerontologic Nursing. $2^{\text {nd }}$ ed. St. Louis: Mosby Company; 2000. 199-216.

9. Mental Health Issues. Depression in Older Adults and the Elderly: Signs, Symptoms, Causes and treatment. 2006. Available from: http://www.helpguid.org/ mental/depression-elderly.htm.

10. Lachine $O$. The effect of a Nursing Intervention Program on the Loneliness Experienced by Elderly People. Unpublished Doctoral Dissertation Thesis, Faculty of Nursing, University of Alexandria, 1998.
11. Arcuri J. Grandparents, Older adults encouraged to seek help for a sleep disorder. 2007. Available from: http://www.americanacademyofslee pmedicine.com

12. The National Center on Sleep Disorder Researches, Sleep Problems. 2005. Available from: http://www.nhlbi.nih.gov/about/ncsdr/.

13. Moore K. Geriatric Nursing. $4^{\text {th }}$ ed. London: Mosby Co.; 1998.

14. Yesavag J. Geriatric Depression Scale. Journal of Psychiatry Research. 1991; 17: 37-49.

15. أمال عبد السميع اباظه مقياس الاكتئاب للمسنين الانين مكتبة الانجلو المصرية. 2000

16. Kane RA, Kane RL. Assessing older persons. $2^{\text {nd }}$ ed. Oxford University Press; 2000. 132-134.

17. Johns $M$. A new method for measuring daytime sleepiness: the Epworth sleepiness scale, Journal of Sleep. 1991; 14: 540-5.

18. Weaver T. Laizner A. Evans L. An instrument to measure functional status outcomes for disorders of excessive sleepiness, Journal of Sleep. 1997; 20: 835-43.

19. Stuart G, Laraia M. Principles and Practice of Psychiatric Nursing. $7^{\text {th }}$ ed. London: Mosby Company; 2001. 806-809.

20. Oppermann P. How to Recognize and Treat Depression in the older adults. 2007. Available from: National Institute of Mental Health website.

http://www.columbiapsych.com/depr ession older.html

21. William J, Paul A. Adult Development and Aging. $5^{\text {th }}$ ed., New York: McGraw-Hill Companies; 2003. 52-54.

22. Bixler $\mathrm{E}$, Vgontzas $\mathrm{A}$, Lin $\mathrm{H}$, et al. Excessive daytime sleepiness in a 
general population sample: the role of sleep apnea, age, obesity, diabetes, and depression, J Clin Endocrinol Metab. 2005, 90: 4510-5.

23. Makhlouf M, Ayoub A, Abdel Fattah M. Insomnia symptoms and their correlates among the elderly in geriatric homes in Alexandria. Journal of Sleep Breath. 2007, 11(3): 187-94.

24. Langlois J, Minicuci N, Foley D. Sleep complaints in community dwelling older persons. Prevalence, associated factors, and reported causes. Journal of American Geriat Soci. 1998; 46(2): 161-98.

25. Sukegawa T. Sleep disturbances and depression in the elderly in Japan, Journal Psychiatry and Clinical Neurosciences. 2003; 57 (3): 265-70.

26. Zulley J, Smirne S, Guilleminault C. Sleep Problems. J Am Geriatr Soc. 2001, 49(4): 360-6.

27. Foly D. Sleep complains among elderly persons: an epidemiologic study in three communities, Journal of Sleep. 1995; 18: 425-32.

28. Foreman $M$, Wykle $M$. Nursing standard of practice protocol: sleep disturbances in elderly patients, Journal of Geriatr Nurs. 1995; 16: 238-43.
29. Fichten C. Poor sleepers who don't complain of insomnia and life style characteristics of older good and poor sleepers, Journal Behavioral Med. 1995; 18: 189-213.

30. Ibrahim N, Maximos M, Saber K. Sleep disturbances in hospitalized patients. Tanta Medical Journal. 1998; 30: 81-107.

31. Loredo J. A fond farewell: Adam Mailgram's Retirement. Health wise. 2005; 25(8): 4-6.

32. Taheri S, Mignot E. The genetics of sleep disorders and activity, Lancet Neurol. 2002; 1: 242-50.

33. Dergance J, Calmbach W. Barriers to and benefits of leisure physical activity in the elderly. The American Geriatric Society. 2003; 51(6):863-8.

34. Struck B, Ross K. Health Promotion in older adults: prescribing exercise for the frail and home bound. Journal of Geriatrics. 2006; 61(5): 22-7. 